REFLECTIONS:

NEUROLOGY AND THE

HUMANITIES

Section Editor

Michael H. Brooke, MD

\title{
Reflections for September
}

C. William Britt, Jr., MD

Address correspondence and reprint requests to Dr. C. William Britt, Jr., 42 E Rowan, Suite B, Spokane, WA 99207 cbritt@inwhealth.net

\section{CHANGING LANDSCAPE}

Reaching for the carafe, Lynn asked, "Would you like more coffee?"

Sitting at the breakfast table, John continued to look out the glass patio slider and did not answer. The leaf-withering chill of late autumn had weathered the landscape.

Lynn finished rinsing the dishes. After draping the dishrag over the spout, she asked, "Did you take your morning pills?"

"Yeah, I took 'em," John said.

"I'm going to work in the church office this morning," Lynn said. "Then I'll pick up groceries for your mother. I'll be back home after I drop them by and fix her some lunch."

"I'm taking the cell phone with me," Lynn said. "You'll call me if the pager goes off?"

Expressionless and still staring outside, John mumbled, "We'll see."

"You'll call?" she asked again.

"All right!" John shouted. "I'll call you before the pager stops beeping!"

Tense and tearful, Lynn hurried from the room. John heard the car start and pull away. He did not leave the table or shift his gaze.

"Transplant Office, Beth Sawyer, Coordinator," came the voice over the phone.

"Oh, Beth, this is Lynn Ellis. I'm calling you about John. He's not right. He's never been like this. He's angry, depressed, won't talk ..."

"Lynn, emotional reactions are common at this stage, leaving the hospital after a severe illness. Waiting for a heart transplant is stressful."

"He'll carry the pager for the call to come right in for the surgery, but ..." Crying, Lynn said, "I'm afraid he's not going to go through with it!"

Beth gave Lynn a moment to compose herself, then said, "I see." She paused before continuing. "John's due for his 1-month check-up next week.
The transplant program has a psychiatric consultant, Dr. Simmons. You come from quite a distance. Let me get an appointment for John on the day you come back to the Heart Institute."

"Thanks," Lynn said between soft sobs.

"I'm Dr. Simmons, John. Have a seat," the doctor said, gesturing to a wing chair opposite his overstuffed recliner. "What brings you here?"

"My wife made this appointment," John replied.

"Well, how are you feeling?" Dr. Simmons asked.

"Tired," John replied. "We had to drive for 4 hours this morning. I'm taking water pills, so we had to stop several times on the way. With all the blood and heart tests and seeing the cardiologist, the appointments took 3 hours. Then I had to come here."

"Are you tired all the time?"

"Yeah," John said. "Not so much when I first wake up, but if I walk anywhere or do anything."

Then Dr. Simmons asked, "How's your mood?"

"My mood? Okay, I guess ... fine," John said, avoiding the doctor's eyes.

"Any stress?" Dr. Simmons asked.

"Well, the waiting, you know ... No, not the ... It's the whole thing. It's driving me nuts."

"Tell me about that. What's driving you nuts?" Dr. Simmons asked.

John thought, 'This jerk— he's pressing me, analyzing me.' Then he said, "Well, getting a new heart, it ... it's ..." John did not continue.

Dr. Simmons said, "How do you feel about that, John?"

John squirmed in the chair. "I think I'll get through it. I think I'll make it."

"That's a thought, not a feeling," Dr. Simmons corrected. "How do you feel about it?"

John looked directly at the doctor and said, "I'll get through it!" In a moment he spoke again, "Look, it's my wife. She's driving me nuts. She's harping all the time, she's ..." 
"Have you been irritable?" interrupted Dr. Simmons.

John had an impulse to deny the assertion. Instead, he leaned back and said, "She wants the surgery to happen right away."

"Don't you?" asked Dr. Simmons.

"No. Well, yes, of course." John paused before continuing, "Look, the sooner it happens, the sooner someone else has to die!"

"I see," Dr. Simmons said. "And that disturbs you?"

"Of course it does. They said it's usually some brain-dead kid, some accident or something."

"And that bothers you?" Dr. Simmons asked.

"Damn right! I saw it in the ICU, this kid in a motorcycle wreck, the family, this huge family ..."

When John hesitated, Dr. Simmons said, "Yes, it's very sad. Happens every day, all over the country. Many young people die tragically. Is that your wife's concern, what she's worried about?"

"No, I don't ... well ..."

"No," Dr. Simmons said coarsely. "She's afraid you'll die before you get a new heart."

Looking away, John said, "I don't deserve it," the words muffled by the tension in his throat.

"Nobody does," Dr. Simmons said.

"All the things I've done, I mean, the way I treated my first wife ..." John continued, "I abandoned my son. I'm the one that ought to be gutted!"

With a slight cock of his head, Dr. Simmons related, "John, it's not about you. It's about the gift."

Still looking away, John said again, "I don't deserve it."

"No, nobody deserves to live at the expense of another," Dr. Simmons replied. "But it's not about that. It's about the gift."

John looked at the doctor, who said, "Some people decide, if a time comes when their internal organs are of no more use to them, are not promoting a meaningful life, to give others a better chance to live. Some families make that choice for their loved one."

"It's a gift to someone unknown. It can't be bought. No one deserves it. It's something that can only be received."

"Well, it's ... there is no way to ..."

"Repay it?” Dr. Simmons interrupted. "No, there isn't." The doctor paused for a moment before asking, "Can you accept it on those terms?"

"The heart," John said, "All the nerves have been cut. It doesn't speed up if you get excited. It doesn't slow down when you're asleep. You can't feel anything. It's just a pump in your chest, someone else's pump."
"Hmmm," intoned Dr. Simmons. After a moment's reflection, he said, "The Maori people of New Zealand have a belief called hau. Sounds just like our word, 'how,' but it's spelled H-A-U. They believe most things come from the forest. If you take something out of the forest and make an object from it, like a tree made into a spear, the spirit of the forest remains within it and accompanies it forever. That object will always be connected spiritually to its origin."

John looked skeptically at Dr. Simmons, who continued, "A transplanted heart is far more than 'just a pump.' It is suffused with the will of the donor and the love of a family, but also with terrible grief. The heart will always be connected spiritually to that person and family. In a strange way, the gift confines the grief and helps make it bearable. But it's a bittersweet gift nonetheless." Dr. Simmons paused for a moment before asking, "Can you accept it?"

John felt an uneasy energy inside, an energy both alarming and hopeful. "Ma-o-ri?" he asked.

"Hau," Dr. Simmons replied. After a few moments he asked, "And how is your wife holding up?"

"Well, she ... she's uptight."

"Naturally. Have you reached out to her, supported her during this time?" Dr. Simmons asked.

"Look, I've been sick and tired."

"John, the families of transplant candidates are in a situation they can't change or control. They face an uncertain outcome of the surgery and medical treatments, and the fear of loss. They need emotional support, too, especially from the one who's sick."

As clearly as if he were sitting in the kitchen again, John heard the car start and the sound of the engine wane as it pulled away.

"When was the last time you told Lynn that you love her?" Dr. Simmons asked.

John recalled the loneliness of Lynn's absence that morning. Shame over his anger pierced him. More deeply felt than shame was horror at the thought of living without her.

"The last time, John?"

"It's been a while," John mumbled.

A timer clanged on the desk. "Time's up," Dr. Simmons indicated. "Let's talk again when you come back for your next check-up," he said while walking across the room.

The creak of the door being opened startled John into motion. He stood, walked out of the room, then turned around just outside the doorway and faced the doctor. Tears filled John's eyes. "I don't deserve it," he said softly.

"No," said Dr. Simmons, who smiled kindly at the sick man before closing the door. 


\section{Neurology}

Reflections for September

C. William Britt, Jr.

Neurology 2010;75;1025-1026

DOI 10.1212/WNL.0b013e3181f25e7c

This information is current as of September 13, 2010

\section{Updated Information \&}

Services

Permissions \& Licensing

Reprints including high resolution figures, can be found at: http://n.neurology.org/content/75/11/1025.full

Information about reproducing this article in parts (figures,tables) or in its entirety can be found online at:

http://www.neurology.org/about/about_the_journal\#permissions

Information about ordering reprints can be found online:

http://n.neurology.org/subscribers/advertise

Neurology ${ }^{\circledR}$ is the official journal of the American Academy of Neurology. Published continuously since 1951, it is now a weekly with 48 issues per year. Copyright . All rights reserved. Print ISSN: 0028-3878. Online ISSN: 1526-632X.

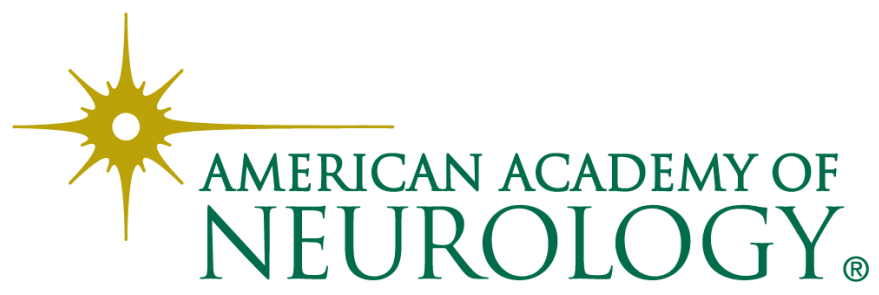

